\title{
International Arctic \\ Petroleum Cooperation
}

Barents Sea scenarios

Edited by Anatoli Bourmistrov, Frode Mellemvik, Alexei Bambulyak, Ove Gudmestad, Indra Overland and Anatoly Zolotukhin

Chapter 6

Norwegian-Russian political relations and Barents oil and gas developments

Indra Overland and Andrey Krivorotov 


\title{
6 Norwegian-Russian political relations and Barents oil and gas developments
}

\author{
Indra Overland and Andrey Krivorotov
}

\section{Introduction}

The political relationship between Norway and Russia will influence the development of Barents Sea oil and gas. The state plays a decisive role in both the Norwegian and Russian parts of the sea. It does so as a regulator, through taxation, and through the national oil and gas companies, Gazprom, Rosneft, and Statoil. Thus, if the two states have a good relationship characterized by mutual trust, they can coordinate, search for complementarities, and mitigate issues that arise. Furthermore, due to the rising cost of oil and gas production in the Arctic, many oil and gas fields there may deliver small returns on investments. Scale economies brought about by coordinated development, joint infrastructure, and information sharing can tip projects from being commercially unviable to viable. But this depends on the ability and willingness of the two states to actively work together.

It is commonly noted that Norway and Russia have been at peace for over 1,000 years (e.g. Støre, 2010). At the end of World War II, North Norway was liberated from Nazi occupation by Soviet forces. During the two first decades after the collapse of the Soviet Union, Russia had better relations with Norway than with many other West European countries (Jensen \& Overland, 2011; Vaage \& Overland, 2011). Norway has not had a highly anti-Russian foreign minister, such as Sweden's Carl Bildt, neither has it had a case such as that of Aleksander Litvinenko in the UK or Akhmed Zakayev in Denmark. Norwegian companies have invested heavily in Russia, not just in the petroleum sector but also in telecoms, the media, and breweries. Some companies have made large profits, in spite of years of continuous quarreling between Norway's Telenor and Russian co-shareholders over a hostile takeover of a Ukrainian mobile operator (Liuhto, 2007). Russian companies, Rosneft and Lukoil, have in turn been allowed onto the Norwegian continental shelf, and Russian tourists are some of the biggest spenders in Norway. Russian students and immigrants have flocked to Norway, thriving there (Bourmistrov, 2007, 2011).

Nonetheless, the bilateral political relationship between the two countries is variable and subject to risks. There are at least two main sources of concern in the relationship between the two countries: their complex direct interaction in 
the Barents Sea, and the broader political relationship between Russia and the West, of which Norway is a part. An accidental entanglement in the Barents Sea could lock the two countries into a negative spiral of actions and counteractions, or a long-term cold front in Russian-Western relations over a matter such as Ukraine could cast long shadows over the bilateral relationship between the two countries.

The Barents Sea and its petroleum province are divided in two by the 1,680-km Norwegian-Russian maritime boundary (Moe, Fjærtoft, \& Overland, 2011; Norwegian Ministry of Foreign Affairs, 2011, p. 61). The length of this boundary, greater than the distance between Berlin and Moscow, means that the two countries have extensive and complex relations. The boundary crosses some of the world's richest fish stocks; Russia's only year-round, ice-free port in the Arctic is the Barents city of Murmansk; the Svalbard Archipelago on the Norwegian side of the boundary is Norwegian territory, but subject to the 1920 Svalbard Treaty, which gives other signatory states including Russia the right to engage in economic, maritime, research, and other activity on the archipelago; and, finally, the Barents Sea is the gateway to the Northern Sea Route leading to the Pacific Ocean. There are thus many opportunities for entanglement between Norwegian and Russian actors, including the joint management of fish stocks, illegal fishing, coast guards arresting fishing vessels, oil spills, nuclear accidents, and so on.

In this chapter we provide a forward-looking overview of the complexities of the relationships between the two countries. However, we start in the next section by looking back at the situation before the 2010 maritime boundary agreement. The subsequent sections deal with the reception of the boundary agreement in Norway and Russia, the place of Barents oil and gas in the broader Norwegian and Russian contexts, the linkages between Norwegian-Russian bilateral relations and broader Russian-Western relations, and implications for the future.

\section{Before the Barents Sea maritime boundary agreement}

The territorial dispute between the USSR/Russia and Norway dated back to the 1960s when the continental shelf came into the political spotlight, both as a promising petroleum province and as an emerging object of international law. The first informal Soviet-Norwegian consultations on the delimitation of the Barents Sea took place in 1970.The official negotiations were launched in 1974 and then held on a largely regular basis. Once the two countries established their 200-nm exclusive economic zones (EEZ) in 1976, the mandate of the negotiations was extented to cover fisheries as well.

The Norwegians adhered to the median line principle, while the Soviet side maintained the straight sector line established by the USSR government in 1926. The overlapping disputed area was about 175,000 square km (some 50,000 square $\mathrm{nm}$ ) large, equivalent to over half of the Norwegian mainland territory (Moe et al., 2011). 
The first 15 years of discussions resulted in virtually no progress. However, the very fact of equal bilateral negotiations between a nuclear global superpower and its small but NATO-member neighbor was of major symbolic importance during the Cold War. Moreover, as early as in 1976, the two countries signed a long-term agreement on cooperation in fisheries and established the Joint Norwegian-Russian Fisheries Commission, which among other things sets agreed catch quotas for common fish stocks in the Barents Sea (Krivorotov, 2011). Besides, in 1978, the USSR and Norway set up a temporary mechanism for regulating fisheries in the disputed area (the so-called Gray Zone agreement), which was later prolonged each year until the 2010 Murmansk Treaty was signed.

Both countries also had reasons to believe that the seabed in the area possessed large potential oil and gas resources, since Norway made numerous offshore discoveries in the North Sea and USSR in the eastern Barents Sea (Moe, 2010). In the early 1980s, a Soviet research vessel shot 2D seismic in the disputed area, which helped to identify several promising prospects, notably including the Fedynsky High. However, soon after, the two countries agreed to refrain from any further exploration in this area, and its actual reserves remain unknown.

In late 1988, the Soviet Foreign Ministry indicated for the first time that the Soviet Union might be willing to deviate from the sector line. After that, the delimitation process started making gradual progress, moving from north to south. When Mikhail Gorbachev visited Oslo as President of the USSR in June 1991, he announced that the borderline issue had already been resolved by two-thirds (Krivorotov, 2001). But in subsequent years, the talks slowed down and nearly stalled, as the negotiations moved on to the southern Barents Sea, which is the most important area for fishermen, oilmen, and navies alike.

The year 2010 finally brought about a real breakthrough in negotiations. At the end of the first visit of the Russian President, Dmitry Medvedev, to Oslo in April 2010, the foreign ministers of the two countries announced that a solution to the Barents Sea dispute had been reached and only details remained before an agreement could be signed (Bakken \& Aanensen, 2010). A few months later, on September 15, the delimitation treaty was signed in Murmansk, dividing the disputed area approximately into two halves of 87,500 square $\mathrm{km}$ each.

The settlement, which was a surprise even to many insiders, apparently came about for several reasons. First, there had been a manifold increase in the level of bilateral relations, mutual interest, and trust over the two past decades. Russia and Norway had entered a number of agreements in various fields, exchanged numerous visits at top and high political levels, promoted mutual trade and investments, and cooperated closely in the High North, both in a bilateral format and within broader international organizations, including the Barents region and the Arctic Council. Second, it was in both countries' interest to settle the territorial dispute in light of the work they were doing to stake their claims for the continental shelf beyond the 200 nautical mile limit. An extra concern for Norway was expanding the part of its seabed available for oil and gas exploration, as its oil production had peaked in 2004 and started to decline. 
Last but not least, Dmitry Medvedev, the pro-Western Russian President of that time, made a personal contribution to move ahead with the settlement. He made this clear in his joint news conference with the Norwegian Prime Minister, Jens Stoltenberg, after signing the treaty (President of the Russian Federation, 2010). This agreement was of high political value that extended far beyond the scope of the bilateral relationship. By ending a decades-old dispute at a time when many observers thought of the Arctic as the object of an intensifying geopolitical competition, two of the major Arctic states sent a clear message to the world that any disputes in the Arctic could and should be resolved peacefully based on international law.

\section{Situation after boundary agreement}

The domestic reaction to the Murmansk Treaty was starkly different in the two countries. In Norway, it was hailed by a vast majority of stakeholders, notably including the parliamentary opposition and most independent experts, as a big step forward. With it, the country had settled the last and by far the biggest territorial dispute it had with its neighbors. The North Norwegian fishermen were the only exception, as they were of the opinion that the deal could lead to a worsening of the situation for the fisheries in the area due to increased oil and gas activity and more lax fisheries protection (Fishermen fear the delimitation line, 2010).

The oil industry and northern regions praised the opportunity to develop oil and gas resources in the delimited area, reversing the negative trend in oil output, creating new jobs, and bringing income to the coastal communities. A large-scale campaign of petroleum exploration in the Arctic fits equally perfectly into the Norwegian government's strategy and rhetoric on the High North (Jensen, 2012). As soon as the Murmansk Treaty came into force, it started sponsoring seismic shooting in the previously disputed area. However, licensing in the area followed the usual path, including the issuing of environmental and social impact assessments, public hearings, etc. Exploration blocks in the southern part of the delimited area were granted for the first time in Norway's twenty-second licensing round, in 2013.

By contrast, in Russia the treaty encountered significant skepticism. Fishermen, backed strongly by the Communist faction in the Duma, came out as the strongest opponents in Russia, as they stated that they were losing access to the rich fishing grounds in the western part of the formerly disputed area, which were now Norwegian waters. Although the joint fisheries management was to remain intact for 15 more years, they feared that their catch quotas would be cut dramatically (Norway to get part of Barents Sea today from Russia, 2010). Another argument against the treaty, closely connected to the first one, was that it did not mention explicitly the special status of, and Russian rights on, Svalbard and in the adjacent waters, including notably Norway's fisheries protection zone around Svalbard, which the USSR/Russia had never acknowledged (Oreshenkov, 2010; Zilanov, 2013). The broader Russian public, which had been unaware of this dispute, also criticized the deal as a unilateral Russian 
concession of its traditional possessions. If it had not been for the ruling party, Unified Russia, which was chaired by then Prime Minister Vladimir Putin, the treaty would likely not have been ratified by the Duma.

Meanwhile, Rosneft, the Russian national oil company, which had for years shown an interest in the Barents Sea shelf, quickly saw the opportunities that the delimitation agreement created, all the more as the recent amendments to the Russian legislation on the continental shelf had made it possible for Rosneft to obtain Arctic shelf acreage without competitive bidding. By early 2012 the Russian part of the delimited area was split into three large blocks, and Rosneft was granted the licenses to all of these.

\section{The Barents Sea in the broader national contexts}

The Arctic in general remains high on the political agenda in both Norway and Russia, with an emphasis on maintaining a presence and leading positions in the Arctic, developing domestic northern regions, and enhancing the national Arctic identity. This may encourage both cooperation and competition, as we have seen in the Arctic since the 1960s.

Despite the high political importance to both countries of oil and gas exploration and development in the Barents Sea, any large-scale investments must be commercially viable and comply with broader national approaches to the countries' petroleum resources. In other words, it is not just a question of Norway and Russia coordinating their efforts in their respective parts of the Barents Sea, but also of how the Barents Sea fits into respectively the broader Norwegian and Russian oil and gas industries.

In this perspective, the situation is asymmetric, as Russia has more domestic alternatives to the Barents Sea than Norway does, and the political context in the two countries is different. This asymmetric situation creates a trend towards an imbalanced development of the Barents Sea: the Norwegian petroleum industry is chased away from Lofoten and towards the Barents Sea, while the Russian petroleum industry is drawn away from Europe and the Barents Sea towards East Siberia and the Far East (although the Russian geopolitical interest in the Barents Sea may only be heightened).

\section{The domestic Norwegian context}

As in northwest Siberia, the producing oil and gas fields in the North Sea are in decline and Norway needs to invest if it wants to maintain the flow of petroleum revenue. In this regard, the two countries are in a similar situation. Although Norway is a much smaller country than Russia and has much less acreage for potential petroleum exploration and extraction, Norway does also have a choice between different petroleum provinces. Three of the main options between which the Norwegians need to prioritize are investing in enhanced oil recovery (EOR) to extend the lifespan of the North Sea fields, or in greenfield areas near the Lofoten Islands, or in the Barents Sea. 
The drivers and debate over priorities in Norway are, however, different from those in Russia. First, there is significantly more emphasis on EOR in Norway. The average rate of recovery in the North Sea is above $50 \%$, whereas in Russia it is below 20\% (Maugeri, 2006, p. 209). In 2014, the Norwegian government established a national center for EOR, further strengthening the emphasis on EOR (University of Stavanger, 2014).

Second, public concern over environmental issues plays a larger role in Norway. This includes both worries over local environmental issues, such as oil spills and conflicts with fisheries, and Norway's contribution to global greenhouse emissions. Sometimes these environmental agendas are debated separately; sometimes they are combined into a general environmental resistance by those lobbying against new oil developments.

One of the main ambitions of the environmentalists has been to avoid oil and gas extraction in the areas around the Lofoten Islands. Meanwhile, other local actors hope for economic benefits from increased petroleum activity in the North and actively promote it. The so-called red-green coalition government of the Center, Labor, and Socialist Left Parties that ruled Norway 2005-2013 was divided on this issue and ended up closing the area for exploration for the time being. This ensures that the matter will reappear on the political agenda during the coming years.

The Lofoten Islands have been a logical target for environmentalists because they are important spawning grounds for cod, and because their natural beauty holds an important place in Norwegian ethnic identity. The Barents Sea is probably at least as environmentally important, and significantly larger, but has still received much less attention. Propetroleum interests have thus grumblingly accepted the moratorium on petroleum exploration in the area around the Lofoten archipelago, while accelerating exploration in the Barents Sea. Thus, paradoxically, environmental resistance may have led to more rapid development of oil and gas in the Barents Sea.

While the Lofoten moratorium may have contributed to speeding up exploration in the Barents Sea, it may also be an obstacle to the development of oil and gas fields found there. This is because it would be more logical to develop the Lofoten Islands first from an infrastructure perspective, as they are located north of the last area to have already been developed, in the Norwegian Sea off central Norway. Should natural gas be found, one could then consider extending the Norwegian offshore pipeline grid northwards to the Lofoten Islands, and then later on to the Barents Sea. With the environmental moratorium on the Lofoten Islands, they become an infrastructural missing link between the undeveloped Barents Sea and the developed southern parts of the Norwegian continental shelf.

For the professional environmentalist NGOs, climate change is as important as, or more important than, local environmental protection. It is, however, more difficult to mobilize the population around climate change, especially the North Norwegian population, who can then feel that it needs to choose between the concrete benefits of jobs and rising property prices on the one 
hand, and the abstract concern of climate change on the other hand (Kristoffersen, 2014; Kristoffersen \& Jensen, 2012).

Another way in which the Norwegian government's choices will play a role is in terms of its policy towards Russia. For Russia, Norway is a small neighbor; for Norway, Russia is its largest, and, importantly, most difficult to understand, neighbor. As mentioned, Norwegian policy towards Russia has been milder and more cooperative than that of some other European countries such as Poland, Sweden, or the UK. There has been a relatively strong, albeit implicit, consensus about this across the Norwegian political spectrum. The main exception is the Venstre Party, which has spoken out for a more critical policy towards Russia (see Borsch, 2012), but this is a small party and all the major parties have de facto supported a foreign policy towards Russia of steadily growing ties and integration. However, this could change. During the 10 -year period that started with Putin's second presidential term in 2004, the attitude of Norwegian officialdom towards Russia has gradually deteriorated, especially since the events in Ukraine in 2014. Norway is also a founding member country of NATO and with strong ties to the UK and the US, potentially sources of influence for a more critical policy towards Russia. However, Norway is closer to Russia and so far the Norwegian elite have still been more cautious than those of many other Western countries in criticizing Russia.

The current coalition government of the Conservative and Progress Parties has continued the discourse on the Arctic but so far has not done much about it. Jonas Gahr Støre was quick to emphasize the High North when he was Foreign Minister under the coalition government that was led by the Labor Party. He has now been elected leader of the Labor Party and has launched climate policy (and possibly interethnic integration) as his main political cause(s). Although it is likely that the Labor Party will return to power in a 10 -year perspective, there is thus little reason to expect that it will lead to a reinvigorated focus on the High North and the development of new oil and gas fields.

\section{The domestic Russian context}

There are more alternatives to the Barents Sea in Russia than in Norway. On the one hand, developing the Arctic shelf enjoys a high priority in the government's plans, as a very visible way to compensate for the falling oil and gas production of the traditional Siberian fields, to establish a presence in the politically sensitive circumpolar area, and to enhance the well-being of the country's northern territories. All the relevant government papers, like the regularly updated National Energy Strategy or the Strategy for the Russian Arctic Zone adopted in 2013 (Government of the Russian Federation, 2009; President of the Russian Federation, 2013), set the goal of creating a new upstream province on the country's Arctic continental shelf, which in the first order means the Barents Sea and eventually the Kara Sea. Russian researchers, although aware of the inherent environmental challenges, advocate strongly for intensified exploration and development of the nation's Arctic shelf, as one of the biggest 
remaining hydrocarbon reserves of global scale (Laverov, Dmitrievskiy, \& Bogoyavlenskiy, 2011; Tsunevskiy, 2008). Gazprom and Rosneft also highlight their Arctic profile as a part of their global market positioning. When crude oil shipments started from the Prirazlomnoye field in the eastern Barents Sea, Gazprom was happy to announce that it had opened a new Russian petroleum production center in the Arctic.

On the other hand, the above plans date back to the time when experts in and outside Russia forecasted a steady growing demand for oil and gas in the Atlantic basin, both in Europe and the United States. There has been a need to reconcile policy goals with changing market realities. First, even regardless of the current strain in Russian-Western relations over Ukraine, both Rosneft and Gazprom have to revisit their market strategies. There has been speculation for some time as to whether Gazprom had to choose between the previously undeveloped Barents Sea and the more "conventional" Yamal Peninsula (Moe, 2006, p. 393). Yamal has the advantage that, in terms of geology and natural conditions, it is nearly identical to other onshore northwestern Siberia areas where Gazprom has proven technologies and decades of experience. This dispute was, however, rather academic as long as all experts foresaw a steady increase in the global demand for fuels, justifying simultaneous on- and offshore developments. But at a time when the United States is turning into a leading global producer and a potential net exporter of gas and perhaps even oil, when natural gas prices face an increased volatility and the EU attempts to reduce its dependence on Russian energy, the priorities may need to be set more clearly. "Gazprom critically analyzes and reviews the strategies it has been following recently," its CEO, Alexey Miller, said in October 2014, addressing the global changes in the natural gas markets. "It doesn't mean that we are going to change these strategies and approaches, but it is possible" (Gazprom, 2014b).

The Ukrainian crisis has added to this strain. By June 2014, Ukraine had accumulated debt for previously delivered Russian gas worth USD 5.3 billion and Gazprom switched to deliveries against advanced payment only. This may lead to Ukraine consuming some of the transit gas delivered from Russia to the EU through its territory, something that has happened before. Both parties have sued each other in the Stockholm Court of Arbitration. Several rounds of tripartite Russia-Ukraine-EU negotiations on gas sales to Ukraine failed to produce an agreed price. Rosneft has also declared the loss of some of its oil in the Ukrainian pipeline network and in addition had to postpone the planned overhaul of its Lisichansk refinery in eastern Ukraine due to the violence in that part of the country (Rosneft plans to seek compensation, 2014). As a result, the Russian oil and gas transit through Ukraine, which had never been easy, became even more unpredictable than ever before, forcing Russia to further intensify its efforts to diversify export routes.

The second point, which is interrelated with the first, is the growing Russian focus on the expanding Eastern Asia markets (China, Japan, Korea, India, etc.). Their demand is big and growing, while natural gas prices are some periods twice as high as in Europe and the US. Besides, energy cooperation with these 
nations gives Russia a strong impetus to develop infrastructure in the adjacent regions of eastern Siberia and the Far East, which are vital to provide Russia with an access to the Asia-Pacific area. Problems in the European market are a secondary, still important, factor to enhance this trend.

In the past few years, Russian companies, backed strongly by the authorities, have committed to supply major quantities of both oil and gas to China. In 2009, the Russian state oil company, Rosneft, signed a deal with the China National Petroleum Corporation (CNPC) to supply $15 \mathrm{mt} / \mathrm{y}$ of oil till 2030, starting in 2012. In 2013, Rosneft signed an additional contract with CNPC for the supply of another $365 \mathrm{mt}$ within 25 years, and also signed a memorandum of understanding with Sinopec to deliver another $100 \mathrm{mt}$ of oil in 2014-2023 (Starinskaya, 2013). Besides their great scope and long-term nature, these contracts have the strong advantage for Rosneft of major advance payments (for example, USD 70 billion under the second Rosneft-CNPC deal alone) (Rosneft receives advance payment from China for oil, 2014). Rosneft has also recently engaged in a number of joint projects with Chinese companies on producing oil in eastern Russia and constructing an oil refinery in China (Rosneft, 2014).

In May 2014 Gazprom signed a contract worth USD 400 billion with CNPC for the delivery of $38 \mathrm{bcm} / \mathrm{y}$ of natural gas from eastern Siberia to China over 25 years starting from 2019. On September 1, 2014 Gazprom started construction of the 4,000-km-long Sila Sibiri [Power of Siberia] gas pipeline (Gazprom, 2014a). At the ceremony Gazprom also indicated that another contract may soon be signed with CNPC for the western route, to transport gas to China from existing fields in western Siberia, which make up the main resource base for deliveries to Europe (though Gazprom maintains that it has enough gas to supply both markets). The framework agreement on the western route was later signed by the two companies on November 9, 2014 under the Asia-Pacific Economic Cooperation Summit in Beijing (Gazprom, 2014c).

Third, as several industry experts and environmentalists have pointed out, there are promising alternatives to increasing upstream production, like enhancing oil recovery from the fields in operation, cutting associated gas flaring, and curbing nonproductive fuel and energy losses under both production and consumption. According to Russian estimates, energy efficiency may be increased by $30 \%$ in national power generation and by $40 \%$ in hot-water supply systems.

The effect of these market-driven changes, which were already well underway before the conflict in Ukraine, on Russia's interest in the Barents Sea may be exacerbated by the Norwegian government's participation in Western criticism and measures against Russia, including economic sanctions. The attempts by the US and EU to isolate Russia highlight the risks involved in close economic relations with them for a government such as that of President Putin, which is not recognized by Western governments as democratic. As predicted and theorized by Overland, Torjesen, and Kjærnet (2010, p. 93), the realization of this risk causes countries with such governments to reorient themselves towards China. 
Seen with Russian eyes, the issue is more fundamental: the West has failed to establish a working global order based on a unilateral dominance, and other nations have to combine their efforts (both in political and economic terms) to construct a more balanced system of relations and protect their legitimate interests. This close interaction of economic, political, and ideological considerations makes the situation both complicated and hard to predict. However, it is rather evident that Russia lacks some key technologies to develop its Arctic shelf, and the US and EU sanctions on the transfer of Arctic and deep-sea oil and gas technologies can help make Russian companies focus more on Siberian onshore fields and Asian markets.

Another factor in the Russian domestic context is the potential changes in the country's company landscape. Novatek and Rosneft actively increase their national gas production and sales, and Gazprom could potentially lose its monopoly on pipeline exports (see e.g. Henderson, 2013; Lunden, Fjærtoft, Overland, \& Prachakova, 2013). Already Novatek has been permitted to launch LNG exports from its Yamal LNG project independently of Gazprom, and Rosneft indicates a strong desire to obtain gas export rights both for LNG and pipeline gas. These changes may further enhance the Russian trend towards the East, since both Novatek and Rosneft seem to be giving high priority to cooperation with China (CNPC already has a 20\% stake in Yamal LNG).

As the scenario horizon of this book is 10 years, which exceeds the constitutional term in office of President Vladimir Putin, it also raises the question of Russian policies in the longer run. The government could, for example, pursue a more liberal Western-oriented policy, or rely more on Asian partners, or become more domestically oriented. This applies to Russian behavior in the Arctic as well - different modes are possible, and the choice among these does not at all depend solely on the personality of the next Russian president. Indeed, the president possesses extensive powers, but the personal factor is often exaggerated (Overland, 2011), as the declared and especially the practical Russian policies are a product of a broader elite and government apparatus. The Arctic shelf is a good example of this. While the Russian laws ban foreign investors explicitly from the shelf resource base, this has not stopped Rosneft and Gazprom from forging offshore partnerships with foreign companies and from suggesting legislative amendments to facilitate this in September 2014 (i.e. when the Western sanctions against Russia had already been imposed). In this respect, the political developments in Russia represent an uncertainty. Russian-Norwegian political relations in the Barents Sea will be a function of, among other things, the broader Russian choices between East and West, plus the general role of the Arctic in the national political agenda.

\section{Concluding thoughts: the broader influence of Russian-Western relations}

All the factors explored above are important to understand the prospects for Norwegian-Russian cooperation. An additional and overarching factor that 
must be considered as we conclude is the broader relationship between Russia and the West. Relations between Russia and the West have entered a spiral of Western sanctions and Russian countermeasures over the conflict in Ukraine. As this book has a 10-year scenario horizon, it is, however, important not to become too caught up in current events - however difficult that is. The longer-term implication of the current impasse is a major break in Russian-Western relations. Even compared to previous negative incidents such as the conflict in South Ossetia, this is worse. Russia and the West appear to be locked into a negative spiral, where it is difficult for either party to offer a compromise. It will be difficult for any future Russian leader to give up or compromise on Crimea, and it will be as difficult for Western leaders to accept Crimea becoming part of the Russian Federation. Once in place, sanctions may be difficult to remove, because it puts the onus of argument on those who want to remove the sanctions. These considerations point towards a long-term worsening of Russian-Western relations.

However, it is also possible that Russia and the West will be forced to find a modus vivendi. Arguments pointing in this direction are a number of common challenges like fighting terrorism and reshaping the global economic order, Russia's dependence on oil and gas revenues, economic collapse of Ukraine (about which both sides may ultimately be obliged to do something), the EU's dependence on Russian energy, and Russia's fear of becoming too dependent on China.

So what then does this imply for Norwegian-Russian relations? One analysis that was carried out before the Ukraine conflict found that Russian-Western political trade had a limited impact on Norwegian-Russian trade and economic cooperation (Vaage \& Overland, 2011). This analysis covered eight previous political spats between Russia and the West. However, none of these quarrels were as severe as that over Ukraine, and none involved formalized sanctions by the West against Russia. In this respect it is clear that the Ukraine crisis is different and will affect the bilateral trade relationship, although it is not possible to say how much and for how long.

What can be said with some confidence is that Norway, in spite of not being an EU member, is highly loyal to EU policy. Although Norway can choose whether or not to follow the EU's lead on Russian policy, any Norwegian government is likely to do so. This is because the main political parties in Norway - the Conservative and Labor Parties - are both firmly pro-EU, and because adhering to EU policy removes the risks involved in formulating an independent policy. As long as Norway consistently follows the EU lead, there is not so much need for the government to explain its choices, as they are made for it by the EU. As soon as Norway deviates from the EU line, the question arises whether it should be more or less lenient and why. Thus, as long as the EU is locked into a formal conflict with Russia through formalized sanctions, Norway is likely to also be so. Since the oil sector was singled out for targeted sanctions early on, this does not bode well for cooperation in the Barents Sea. 
On the Russian side, the Russian-Western distrust over Ukraine is highly negative for Russian interest in the Barents Sea because the Russians are already so dependent on European gas markets. Events in Ukraine make Russia want to diversify export markets towards Asia faster, and the Barents Sea is just about as far away from Asia as one can get on the planet. At the same time, tensions with the West may strengthen Russian security and military attention regarding the Barents Sea, which might add additional negativity to the prospects for Norwegian-Russian cooperation in the area.

In the past there have been suggestions for Norwegian-Russian joint infrastructure for the transport of natural gas from the Barents Sea to markets, either in terms of extending the Norwegian offshore gas pipeline grid northwards to the Barents Sea (Barlindhaug, 2005), or in terms of building a pipeline from the Murmansk to Hammerfest so that Russia could use the Norwegian LNG capacity to export Shtokman gas when suitable and the Norwegians could pump their gas in the other direction and use the planned Murmansk-Vyborg pipeline to export gas to Europe when suitable (proposed by Karen Sund of Sund Energy, personal communication). One problem with these propositions is that they would increase Russia's dependence on transit countries, which it is generally trying to reduce (as well as increasing Norway's mutual dependency on Russia). However, in the context of a continuing standoff between the EU and Russia, such proposals might gain new currency if they helped dissipate mutual fears by mixing Russian with Norwegian gas.

\section{References}

Bakken, L.O., \& Aanensen, K. (2010). Historisk løsning av delelinjen [Historical solution of boundary dispute]. Norsk rikskringkasting. Retrieved from www.nrk.no/

Barlindhaug, J.P. (2005). Petroleumsvirksomhet $i$ Barentshavet [Petroleum activities in the Barents Sea]. Tromsø, Norway: Barlindhaug.

Borsch, R. (2012, October 25). Holdningsløs Russland-politikk [Spineless policy towards Russia]. Norsk rikskringkasting. Retrieved from www.nrk.no/

Bourmistrov, A. (2007). Norwegian-Russian cooperation in business education and research:Visions and challenges in perspectives of the High North. Oslo, Norway: Cappelen.

Bourmistrov, A. (2011). Perspectives on Norwegian-Russian cooperation in the field of energy. Oslo, Norway: CappelenDamm.

[Fishermen fear the delimitation line] Fiskere frykter delelinjen. (2010, June 25). Norsk rikskringkasting. Retrieved from www.nrk.no/

Gazprom. (2014a, September 1). Power of Siberia construction launched [Press Release]. Retrieved from www.gazprom.com/press/news/2014/september/article200026/

Gazprom. (2014b, October 7). Speech by Alexey Miller about global gas industry outlooks and problems at 4th St. Petersburg International Gas Forum [Press Release]. Retrieved from www.gazprom.com/press/miller-journal/285476/

Gazprom. (2014c, November 9). Russia and China sign framework agreement on gas supplies via western route [Press Release]. Retrieved from www.gazprom.com/press/ news/2014/november/article205898/

Government of the Russian Federation. (2009). Энергетическая стратегия России на период до 2030 года [The energy strategy of Russia for the period until 2030]. Retrieved from http://minenergo.gov.ru/aboutminen/energostrategy/ 
Henderson, J. (2013). Evolution in the Russian gas market: The competition for customers (Report No. NG 73). Retrieved from the Oxford Institute for Energy Studies website www. oxfordenergy.org/wpcms/wp-content/uploads/2013/01/NG_73.pdf

Jensen, L.C. (2012). Norway on a high in the North: A discourse analysis of policy framing (Doctoral thesis, University of Tromsø, Tromsø, Norway). Retrieved from http://munin.uit. no/handle/10037/4737

Jensen,V., \& Overland, I. (2011). Et blikk på Sjtokmanprosjektets blindsone: fransk-russiske relasjoner [A glance at the blind zone of the Shtokman project: French-Russian relations]. Internasjonal Politikk, 69(3), 387-411.

Kristoffersen, B. (2014). Securing geography: Framings, logics and strategies in the Norwegian High North. In R. Powell \& K. Dodds (Eds.), Polar geopolitics? Knowledges, resources and legal regimes (pp. 131-148). Cheltenham and Northampton, MA: Edward Elgar.

Kristoffersen, B., \& Jensen, L.C. (2012). Nordområdepolitikken: A license to drill? [The Arctic policy: A license to drill?]. Tvergastein, 1(2), 74-80.

Krivorotov, A. (2001). Barents Sea: Oil riches in a Cold War playground. Oil\&Gas Eurasia, $1,8-16$.

Krivorotov,A. (2011).Неравный раздел пополам:к подписанию российско-норвежского договора о разграничении в Арктике [Partition into unequal halves: On the signing of the Russian-Norwegian treaty on maritime delimitation in the Arctic]. Vestnik Moskovoskogo Universiteta, 25(2), 62-91.

Laverov, N., Dmitrievskiy, A., \& Bogoyavlenskiy, V. (2011). Фундаментальные аспекты освоения нефтегазовых ресурсов арктического шельфа России [Fundamental aspects of developing hydrocarbon resources of the Russian Arctic shelf]. Arktika. Ekologia $i$ Ekonomika, 1, 26-37.

Liuhto, K. (2007). A future role of foreign firms in Russia's strategic industries (Report No. 4/2007). Retrieved from www.utu.fi/fi/yksikot/tse/yksikot/PEI/raportit-ja-tietopaketit/Docu ments/Liuhto04_07.pdf

Lunden, L.P., Fjærtoft, D., Overland, I., \& Prachakova, A. (2013). Gazprom vs. other gas producers: Friends or foes? Energy Policy, 61, 663-670.

Maugeri, L. (2006). The age of oil:The mythology, history, and future of the world's most controversial resource. Westport, CT: Praeger.

Moe,A. (2006). Sjtokman-beslutningen: Forklaringer og implikasjoner [The Shtokman decision: Explanations and implications]. Nordisk Østforum, 20(4), 389-403.

Moe,A. (2010). Russian and Norwegian petroleum strategies in the Barents Sea. Arctic Review on Law and Politics, 1(2), 225-248.

Moe, A., Fjærtoft, D., \& Overland, I. (2011). Space and timing: Why was the Barents Sea delimitation dispute resolved in 2010? Polar Geography, 34(3), 145-162. doi:10.1080/10 88937X.2011.597887

[Norway to get part of Barents Sea today from Russia] Сегодня Норвегия получит от России часть Баренцева моря. (2010, September 15). REGNUM News Agency. Retrieved from www.regnum.ru/

Norwegian Ministry of Foreign Affairs. (2011). Nordområdene. Visjon og virkemidler [The High North.Visions and strategies] [White Paper]. Oslo, Norway: Author.

Oreshenkov, А. (2010). Арктический квадрат возможностей. Северный полюс и шельф Шпицбергена не могут быть норвежскими [Arctic square of opportunities. North Pole and Spitsbergen shelf cannot belong to Norway]. Rossiya v Mirovoy Politike, 8(6), 194-202.

Overland, I. (2011). Close encounters: Russian policy-making and international oil companies. In J.Wilhelmsen \& E. Wilson Rowe (Eds.), Russia's encounter with globalization: Actors, processes and critical moments (pp.134-158). Basingstoke, England: Palgrave Macmillan. 
Overland, I., Torjesen, S., \& Kjærnet, H. (2010). China and Russia: Partners or firewalls for the Caspian petro-states? In I. Overland, H. Kjærnet, \& A. Kendall-Taylor (Eds.), Caspian energy politics: Azerbaijan, Kazakhstan and Turkmenistan (pp. 93-100). London, England: Routledge.

President of the Russian Federation. (2010,September 15).Совместная пресс-конферениия по итогам российско-норвежских переговоров [Joint news conference concluding Russian-Norwegian talks] [Press Release]. Retrieved from http://news.kremlin.ru/ transcripts/8924

President of the Russian Federation. (2013). Стратегия развития Арктической зонь Российской Федерации и обеспечения национальной безопасности на период до 2020 года [Strategy for developing the Arctic zone of the Russian Federation and protecting national security for the period till 2020]. Retrieved from http://government. $\mathrm{ru} / \mathrm{news} / 432$

Rosneft. (2014, November 10). Rosneft delegation took part in the APEC summit [Press Release]. Retrieved from www.rosneft.com/news/today/10112014.html

Rosneft plans to seek compensation from Ukraine for shelling of oil refinery. (2014, August 31). ITAR-TASS News Agency. Retrieved from http://en.itar-tass.com/

Rosneft receives advanced payment from China for oil. (2014, January 15). RIA Novosti. Retrieved from http://en.ria.ru/

Starinskaya, G. (2013, October 23). “Роснефть” зальет Китай нефтью [Rosneft to pour China plenty of oil]. Vedomosti. Retrieved from www.vedomosti.ru/

Støre, J.G. (2010). Russland som stormakt: Ånningsforedrag ved Forsvarets Hogskole, sjefskurs nr 5 , Oslo, 18. august 2010 [Russia as a great power: Opening lecture at Norwegian Defense University College, Chief Course No. 5, Oslo, August 18, 2010]. Retrieved from www. regjeringen.no/nb/dokumentarkiv/stoltenberg-ii/ud/taler-og-artikler/2010/russland_ stormakt.html?id $=612800$

Tsunevskiy, A. (2008). Арктический шельф - будущее нефтедобычи России [Offshore Arctic Russia's oil industry future]. Energeticheskaya politika, 1, 1-17.

University of Stavanger. (2014, March 24). Tord Lien åpner nasjonalt senter for oljeutvinning [Tord Lien opens the National IOR Centre of Norway] [Press release]. Retrieved from www.uis.no/om-uis/nyheter-og-presserom/tord-lien-aapner-nasjonalt-senter-foroljeutvinning-article85727-8108.html

Vaage, T., \& Overland, I. (2011). Norsk-russisk handel, noe for seg selv? Nord-Norge i et globaliseringsperspektiv [Norwegian-Russian trade, a law unto oneself? Northern Norway in a globalization perspective]. In S. Jentoft, J.I. Nergård, \& K.A. Røvik (Eds.), Hvor går Nord-Norge? Tidsbilder fra en landsdel i forandring [Where does Northern Norway go? Time pictures from a changing region] (pp. 203-212). Tromsø, Norway: Orkana forlag.

Zilanov,V. (2013). Россия теряет Арктику? [Is Russia losing the Arctic?]. Moscow, Russia: Algoritm. 